\title{
Spatio-temporal variations of tropospheric nitrogen dioxide in South Mato Grosso based on remote sensing by satellite
}

\author{
Amaury de Souza $^{1}$ ( $\cdot$ Flavio Aristone ${ }^{1} \cdot$ Marcel Carvalho Abreu $^{1} \cdot$ José Francisco de Oliveira-Júnior ${ }^{1}$. \\ Widinei Alves Fernandes ${ }^{1}$. Ivana Pobocikova ${ }^{1}$
}

Received: 16 July 2021 / Accepted: 13 December 2021 / Published online: 20 January 2022

(C) The Author(s), under exclusive licence to Springer-Verlag GmbH Austria, part of Springer Nature 2021

\begin{abstract}
The study evaluates the characteristics of tropospheric nitrogen dioxide $\left(\mathrm{NO}_{2}\right)$ concentrations from 2005 to 2020 in eight cities in the State of Mato Grosso do Sul (MS), Midwestern Brazil, using data available from the Ozone Monitoring Instrument (OMI). The average concentration varies from $2981 \times 10^{15}$ molecules $/ \mathrm{cm}^{2}$ in Campo Grande, where commercial, industrial and vehicular activities take place, to $2906 \times 10^{15}$ molecules $/ \mathrm{cm}^{2}$ in Corumbá and $3035 \times 10^{15}$ molecules $/ \mathrm{cm}^{2}$ in Porto Murtinho, regions of livestock and biomass burning. The results, based on the Mann-Kendall (MK) test, show a significant increase $(p<0.05)$ in the $\mathrm{NO}_{2}$ column levels in the region. For each of the eight cities studied, a significant seasonal cycle of $\mathrm{NO}_{2}$ columns was determined. The maximum value of $\mathrm{NO}_{2}$ concentration was observed in the dry period, from July to September, while the minimum value was registered in the rainy period, from October to March.
\end{abstract}

\section{Introduction}

Nitrogen dioxide $\left(\mathrm{NO}_{2}\right)$ is a reactive and short-lived gas, with natural and anthropogenic sources, are harmful contaminants, as they are associated with adverse effects on human health, especially with regard to respiratory diseases, and the environment (Souza et al. 2018a, b). The main sources of $\mathrm{NO}_{2}$ are fossil fuel combustion, biomass burning, soil emissions and lightning (Hagenbjörket et al. 2017). $\mathrm{NO}_{2}$ is a toxic air pollutant in the high-concentration condition and plays an important role in tropospheric chemistry as a precursor of tropospheric ozone and secondary aerosols (Jiang et al. 2021; Fan et al. 2021; Castellanos and Boersma 2012; Grajales and Baquedo-Bernal 2014; Fantozzi et al. 2015; Griffin et al. 2018; Xue et al. 2020; Nakada and Urban 2020). Observations of the space-time variations of $\mathrm{NO}_{2}$ form the basis for understanding the spatial distributions and temporal trends of $\mathrm{NO}_{2}$. Nonetheless, the limitation on insufficient spatial and temporal coverage of ground-level

Responsible Editor: Sang-Woo Kim.

Amaury de Souza

amaury.de@uol.com.br

1 Universidade Federal de Mato Grosso do Sul, Campo Grande, MS, Brazil monitoring networks is the main challenge to understand the $\mathrm{NO}_{2}$ dynamics in the atmosphere.

Many techniques and methods have been used successfully in monitoring atmospheric $\mathrm{NO}_{2}$ based on in situ surface measurements, remote sensing from satellite sensors and ground-based instruments (Xiao et al. 2018; Drosoglou et al. 2018). Although in situ measurements and remote sensing of ground-based instruments show high accuracy and precision, their usefulness in determining the spatiotemporal distributions of trace gases is limited due to their sparse spatial and temporal coverage. Space-based measurements provide information on large-scale $\mathrm{NO}_{2}$ distributions and in areas where in situ and ground-based systems cannot be easily deployed (Lamsal et al. 2010). Measurement of atmospheric $\mathrm{NO}_{2}$ is ordinarily obtained from in situ data of air quality stations (AQS) (Fan et al. 2020). However, AQS lack space-time coverage, particularly in countries like Brazil, where measurements are restricted to metropolitan regions (MR)—(Zeri et al. 2011, 2016). On the other hand, the data obtained via Remote Sensing provide data with larger spatiotemporal coverage in relation to AQS and without failures or discontinuities in their time series. Satellite observations provide $\mathrm{NO}_{2}$ data from the total tropospheric column over an area, while AQS measures locally (Richter et al. 2005).

The first $\mathrm{NO}_{2}$ monitoring in the troposphere started in 1995 using the Global Ozone Monitoring Experiment (GOME) on the European Remote Sensing Satellite-2 
(ERS-2). Ozone Monitoring Instrument (OMI) started aboard the Aura satellite in 2002, and in 2004 the new GOME-2 began to collect data. The Tropospheric Monitoring Instrument (TROPOMI) aboard the Precursor Copernicus Sentinel-5 satellite started in 2017. The OMI measures atmospheric $\mathrm{NO}_{2}$ daily since late 2004 with spatial resolution of $13 \times 24 \mathrm{~km}$ in the nadir visualization, increasing the size to $24 \times 135 \mathrm{~km}$ for widest viewing angles. Several studies have been performed using satellite observation data of tropospheric $\mathrm{NO}_{2}$ columns (Richter et al. 2005; Castellanos and Boersma 2012; Schneider and Van Der 2012; Lelieveld et al. 2015; Khokhar et al. 2015; Irie et al. 2016; Cai et al. 2018; Yanfang et al. 2019; Yavaşl 2020; Zheng et al. 2018), and they show that its concentrations are dependent on economic, industrial, and other human-controlled activities but not correlated to emission policies to improve air quality. Several inventories on both global and regional scales of $\mathrm{NO}_{2}$ concentrations normally use regression models for trending analysis. Nevertheless, verification of tropospheric
$\mathrm{NO}_{2}$ trends has not yet been carried out for the State of MS, Brazil. In this paper, the tropospheric concentration of $\mathrm{NO}_{2}$ is analyzed for the period 2005-2020 throughout the available OMI data. It has been highlighted of the characteristics of the spatial distribution of $\mathrm{NO}_{2}$ using the Kendall seasonal test for each pixel.

\section{Materials and methods}

\subsection{Area of study and meteorological data}

The State of MS is located in the Midwest Region of Brazil and encompasses approximately $358,159 \mathrm{~km}^{2}$, see Fig. 1a. It is known for its agricultural activities, the main economic products of MS being soybean and beef cattle production. The State topography is represented in Fig. $1 \mathrm{~b}$ and shows elevation ranging from 24 to $1100 \mathrm{~m}$ (Teodoro et al. 2016).
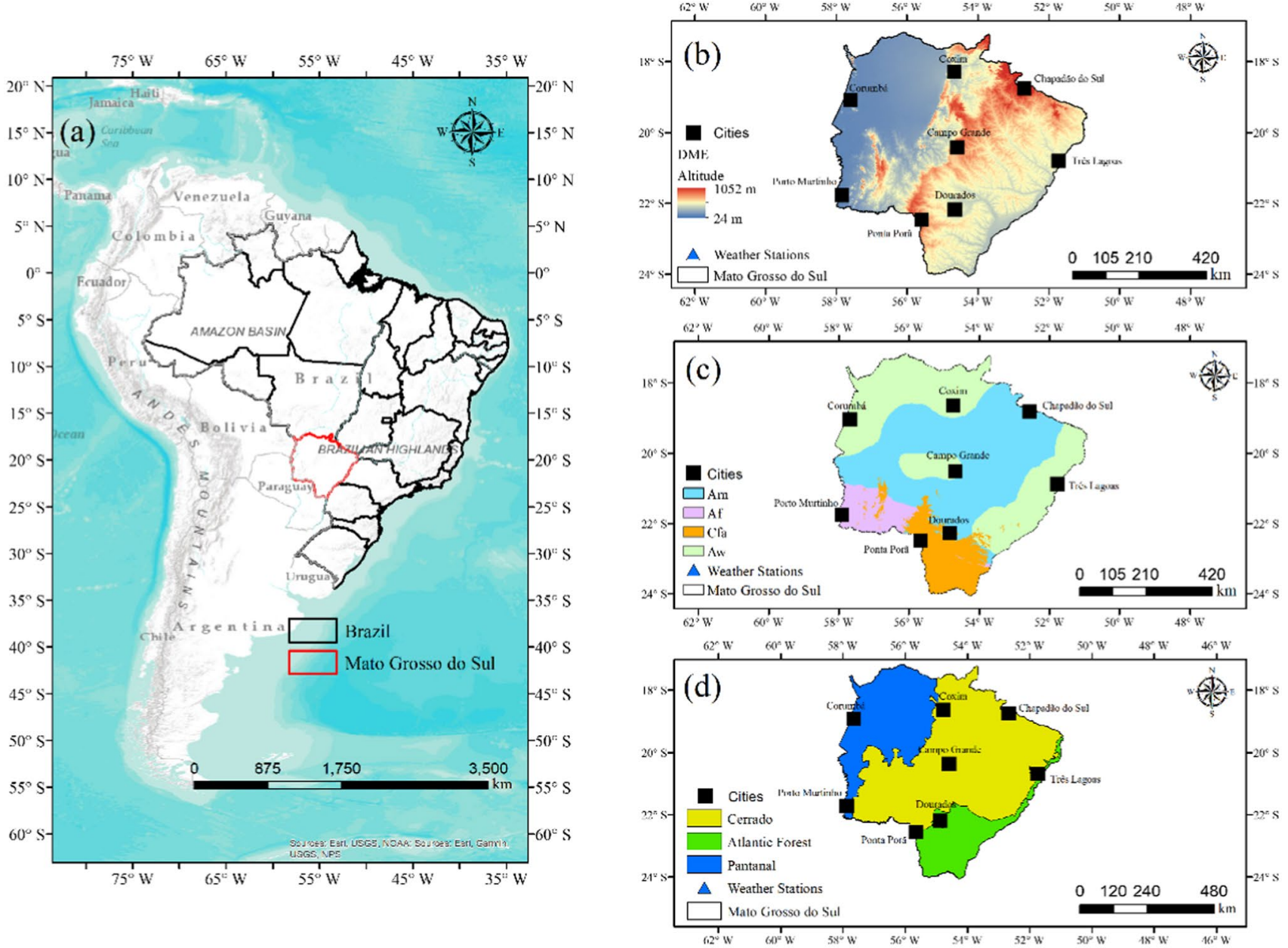

Fig. 1 South Mato Grosso State in Brazil. a Model of Digital Elevation (MDE); b climate classification by Köppen; c biomes; d localization of studied cities 
The average annual temperature varies from 20 to $26^{\circ} \mathrm{C}$, and the mean annual rainfall ranges from 1000 to $1900 \mathrm{~mm}$. The climate presents well-defined dry seasons from April to September, when the higher rainfall records are observed in the southern portion of the state. The rainy season goes from October to March, the northern region of the State receives higher rainfall records compared to the southern region. The Köppen's classification divides the climate diversity of MS into several regions: (1) "Aw" in the Southeast and Northern parts of the state; (2) "Am" for the central region; (3) "Af" in the Southwest; and (4) "Cfa" in the Southern, see Fig. 1c. In the Southwest portion of MS, south of the Pantanal region, which lies between $-21^{\circ}$ and $-22^{\circ}$ latitude, the climate is characterized as tropical forest ("Af"), with rainfalls distributed throughout the year. The central portion of the State is predominantly characterized by tropical monsoon climate ("Am"), with a small dry season during winter. In the northern part, in a small portion of the central region, and the Southeastern region of the state, the climate is characterized as savannah ("Aw"), which tends to present dry winters and rainy summers. Only in the Southern of the state, the climate is humid during all seasons ("Cfa"), with hot summers and average temperatures above $22^{\circ} \mathrm{C}$ (Souza et al. 2012; Alvares et al. 2013).

The biome diversity of MS is represented in Fig. 1d. It includes areas of the Atlantic Forest, the Cerrado, and the Pantanal with $14 \%, 61 \%$, and $25 \%$ of the state-encompassed area. The Atlantic Forest is particularly an important biome due to its abundant biological diversity. It has gained substantial interest as a conservation area since this biome has been considerably reduced in the past. The Brazilian Cerrado is a vast tropical savanna ecoregion widely known for its native habitats and rich biodiversity. It represents the second largest biome in South America, after the Amazon. The Cerrado of South Mato Grosso is located in two hydrographic regions of Brazil, represented by the rivers Parana and Paraguay. The Pantanal is the world's largest inland flooded grasslands and savannas wetland region. It is home to rich wildlife and worldwide known for its unique biome. The region is considered delicate regarding biodiversity due to environmental degradation and damage (Teodoro et al. 2016).

Eight cities of South Mato Grosso have been studied in this paper. These cities are, the State capital Campo Grande, Chapadão do Sul, Corumbá, Coxim, Dourados, Ponta Porã, Porto Murtinho, and Três Lagoas, all represented in Fig. 1. They have been chosen accordingly the availability of meteorological and $\mathrm{NO}_{2}$ concentration data, expressed in $10^{15}$ molecules $/ \mathrm{cm}^{2}$, for the period from 2005 to 2020 . The meteorological data series have been collected from the Brazilian National Water Agency (ANA) database, from Hidroweb (www.snirh.gov.br/hidroweb/publico/medicoes_histo ricas_abas.jsf), and from the Brazilian National Institute of Meteorology (INMET) (www.inmet.gov.br), all accessed in in January 2021. The data include time series of maximum and minimum air temperature, i.e., $T_{\max }$ and $T_{\min }$, respectively, relative humidity (RH) in $\%$, and precipitation (Prec) in $\mathrm{mm}$. A summary of the meteorological conditions for the studied period is presented in Table 1 .

The eight cities have different characteristics related to geographic position, population and main economic activities, as follows: (1) Coxim, located in the Cerrado region of influence, with small patches of open fields. It presents itself in its different physiognomies and in enclaves with the Seasonal Forest. The planted pasture is expressive in the central portion of the municipality. Its economy is strongly linked to fishing, culture, livestock and agriculture tourism; (2) Três Lagoas, the predominant vegetation is the Cerrado with strips of Atlantic Forest. Its economy is strongly linked to fishing, livestock and pulp tourism. It is the third most populous city in MS State, with a population of around 123,000 inhabitants; (3) Campo Grande, the State capital, is located on the watershed of the Paraná and Paraguay River basins. The Guarani Aquifer passes under the city, being the capital of the State holding the largest percentage of the Aquifer within the Brazilian territory, the predominant vegetation being the Cerrado. Its economy is strongly linked to tourism and agriculture. It is the third largest and most developed urban center in the Midwest Region of Brazil, and the most populous city in MS and the 19th most populous in Brazil; (4) Chapadão do Sul, located in the Cerrado region
Table 1 Weather stations in South Mato Grosso: cities, latitude $\left({ }^{\circ}\right)$, longitude $\left(^{\circ}\right)$, altitude (m), minimum and maximum temperatures $\left({ }^{\circ} \mathrm{C}\right)$, average and standard deviation of precipitation $(\mathrm{mm})$, and number of inhabitants

\begin{tabular}{lccccccc}
\hline City & Lat $\left({ }^{\circ} \mathrm{S}\right)$ & Lon $\left({ }^{\circ} \mathrm{W}\right)$ & Alt $(\mathrm{m})$ & $T_{\min }\left({ }^{\circ} \mathrm{C}\right)$ & \multicolumn{1}{c}{$T_{\max }\left({ }^{\circ} \mathrm{C}\right)$} & Prec $(\mathrm{mm})$ & Inhab \\
\hline Coxim & -18.51 & -54.76 & 238 & $22.4 \pm 2.33$ & $30.29 \pm 9.08$ & $1350.6 \pm 60.18$ & 33,459 \\
Três Lagoas & -20.75 & -51.68 & 319 & $20.71 \pm 2.66$ & $30.77 \pm 2.67$ & $1229.8 \pm 83.00$ & 123,281 \\
Campo Grande & -20.44 & -54.65 & 712 & $19.89 \pm 2.34$ & $27.49 \pm 8.21$ & $1422.3 \pm 191.73$ & 792,252 \\
Chapadão do Sul & -18.79 & -52.62 & 786 & $19.48 \pm 2.35$ & $27.3 \pm 8.16$ & $1684.8 \pm 212.32$ & 25,865 \\
Ponta Porã & -22.54 & -55.73 & 755 & $18.48 \pm 2.76$ & $25.91 \pm 7.76$ & $1530.9 \pm 203.98$ & 93,937 \\
Corumbá & -19.01 & -57.65 & 118 & $22.34 \pm 2.91$ & $30.88 \pm 9.19$ & $1519.1 \pm 27.8$ & 12,058 \\
Porto Murtinho & -21.70 & -57.88 & 90 & $22.77 \pm 2.23$ & $30.64 \pm 9.19$ & $1306.2 \pm 20.65$ & 17,298 \\
Dourados & -22.22 & -54.81 & 430 & $19.26 \pm 2.99$ & $27.55 \pm 8.22$ & $1455.8 \pm 113.7$ & 225,495 \\
\hline
\end{tabular}


of influence, in the northeast of the State of MS. It is one of the cities of MS State with the highest altitude (around $900 \mathrm{~m}$ ) and population around 25 thousand inhabitants. (5) Ponta Porã, on the border with Paraguay, with predominance of clean fields, formed by large areas of low grass, constituting the famous natural pastures. Its economic activities are cattle raising, agriculture, wood extraction. Ponta Porã is in the Cerrado area, but in transition with the Mata Atlantica biome. The population is approximately 95,000 inhabitants; (6) Corumbá, on the border with Paraguay and Bolivia, in a Pantanal biome region with a rich and varied vegetation, which includes the typical fauna of other Brazilian biomes, such as the Cerrado, the Caatinga and the Amazon region. The nutritious sludge layer that remains in the soil after flooding allows for the development of a rich flora. In areas where floods dominate, but which are dry during the winter, vegetations, such as carandá and paratudal palms, occur. Its economy is quite diversified, highlighting the activities of mining, fishing and tourism, and agriculture. The highest rates of fires in MS occur in the region of Corumbá. The population of Corumbá is 112,000 inhabitants. (7) Porto Murtinho, in the Pantanal biome, in a transition area with the Cerrado, distributed almost equitably, the coverage is typical of the Pantanal (Cerrado Estépico). There is also cultivated pasture and some crops, the most representative activity is agriculture and was a great producer of mate. The population of Porto Murtinho is around 15,000 inhabitants. (8) Dourados, its natural vegetation is clear fields, also having large parts of Cerrados and large patches of tropical forests, since it is located in area Atlantic Forest area but in a transition area Atlantic Forest-Cerrado. Its economy is mainly based in agriculture and planted pasture. It is the most populous city in the interior of MS State, with a population of approximately 228,000 inhabitants.

\subsubsection{OMl sensor data}

For the analysis, data were collected in grid format with spatial resolution of $1^{\circ} \times 1^{\circ}$ and daily temporal resolution referring to areas in the regions of Mato Grosso do Sul aboard the Aura satellite in 2004. The main objective of the OMI is to obtain global measurements at high spatial and spectral resolution of a series of trace gases in the troposphere and stratosphere (Levelt et al. 2006). It can distinguish between types of aerosols, such as smoke, dust and sulfates (Duncan et al. 2013). According to Torres et al. (2013), this is done through the OMAERUV algorithm that uses pre-computed reflectance from the upper atmosphere for a set of 21 aerosol models composed of three types of aerosols (dust, carbonaceous aerosols, sulfate-based aerosols).

As described on the project's own page, the OMI is a nadir imaging spectrograph that measures solar radiation backscattered by the Earth's atmosphere and surface over the entire wavelength range from 270 to $500 \mathrm{~nm}$ with a spectral resolution of about $0.5 \mathrm{~nm}$. The ratio of the calibrated radiance and irradiance is equal to the Earth's atmospheric bidirectional scattering distribution function (BSDF). Light entering the telescope is depolarized using a scrambler and then split into two channels: the UV channel with a wavelength range $270-380 \mathrm{~nm}$ and the VIS channel with a wavelength range 350-500 $\mathrm{nm}$ (Levelt et al. 2006). These factors are important to obtain the concentration of trace gases and to allow the IMO to monitor tropospheric pollution phenomena, such as biomass burning and industrial pollution, as the tropospheric pollution record is essential to study the human impact on the Earth's atmosphere and climate (Dobber 2006).

\subsection{Preliminary analysis}

The preliminary analyses consist of establishing position and dispersion statistics of notched box-plot for the $\mathrm{NO}_{2}$ concentration. The medians obtained for the listed cities in MS on a monthly scale are then compared.

\subsection{Trend analysis of $\mathrm{NO}_{2}$ concentration}

The trend analysis has been applied to the monthly data. The Mann-Kendall (MK) non-parametric test (Mann 1945; Kendall 1975) has been applied to define the trend. The linear regression analysis to verify the proportion of increase or decrease of the response variable is based on the slope of the characteristic function. The Pettitt test (1979) has been applied to verify the point of interruption of the line (beginning of the trend). The estimated slope of the trend is calculated using a generalized version of Sen's slope estimator (Sen 1968).

The MK is the trend verification test recommended by the World Meteorological Organization (WMO), widely used in hydrological studies (Burn et al. 2011; Sa'adi et al. 2019). It tests whether the series presents a downward or upward trend. The null hypothesis means that there is no trend. For a time series, the Mann-Kendal $(S)$ statistic is defined by:

$S=\sum_{k=1}^{n-1} \sum_{i=k+1}^{n} \operatorname{sgn}\left(x_{i}-x_{k}\right)$

where $x_{i}$ is the $i$-th observation and $x_{k}$ is the $k$-th observation immediately after the $i$-th observation, $n$ is the number of elements in the time series. The variance is determined by the following relationship:

$\operatorname{Var}(S)=\frac{n \cdot(n-1) \cdot(2 n+5)-\sum_{i=1}^{m} t_{i}\left(t_{i}-1\right) \cdot\left(2 \cdot t_{i+5}\right)}{18}$ 
where $m$ is the number of tied groups, $t_{i}$ is the number of loop lengths equal to $i$.

The MK test requires that the sample data are serially independent, i.e., absence of autocorrelation. Correlated sample data in series affect the test ability to correctly assess the significance of the trend. To eliminate any effect of serial correlations in the MK test, autocorrelation analysis has been performed. A correlogram gives a summary of correlations at different periods of time. It consists of the graphic analysis of the autocorrelation function for sequential values of delay $k=0,1,2, \ldots, n$. In the occurrence of verified autocorrelation, the MK test was applied with the modification proposed by Yue and Yang (2004). This modification involves a variance correction to address the issue of serial correlation in the trend analysis, maintaining the significance of the test (Sa'adi et al. 2019).

Regression analysis provides the trend rate using the slope of the resulting function. The slope value indicates the magnitude of the trend while the sign $( \pm)$ indicates an increase or decrease behavior of the tested variable. However, the slope must be confirmed by the Student's t test for statistical significance, i.e., whether it differs from zero or not.

The Pettitt test (1979) uses the Mann-Whitney $U_{(t, M)}$ statistic to verify whether two samples belong to the same population. Thus, the test places the data series in two samples: $x_{1}, x_{2}, \ldots, x_{t}$ and $x_{t+1}, x_{t+2}, \ldots, x_{n}$, to calculate $U_{(t, M)}$ as follows (Kengni et al. 2019):

$U_{(t, n)}=U_{(t-1, n)}+\sum_{j=1}^{n} \operatorname{sgn}\left(x_{t}-x_{j}\right)$

with:

$\operatorname{sgn}=(x) \begin{cases}1, & \text { when } x>0 \\ 0, & \text { when } x=0 \\ -1, & \text { when } x<0\end{cases}$

Pettitt statistics account for the number of exceedances in which the value of the first sample exceeds that of the following sample. The null hypothesis of the test is that there is no breaking point in the data series. The level of significance is adopted 5\%, as assumed by other authors (Uliana et al. 2015).

\subsection{Principal components of $\mathrm{NO}_{2}$ concentration}

Principal component analysis (PCA) was performed to explain the variance structure of the data through linear combinations of the original variables. The variables used were: $\mathrm{NO}_{2}$ concentration $\left(10^{15}\right.$ molecules $\left./ \mathrm{cm}^{2}\right)$, maximum $\left(T_{\max }\right)$ and minimum $\left(T_{\min }\right)$ temperature of the air $\left({ }^{\circ} \mathrm{C}\right),(\mathrm{RH})$ relative humidity (\%), and (Prec) precipitation $(\mathrm{mm})$ for the
MS cities. PCA allows the use of variables correlated with each other, to form components capable of explaining the variance of the data. The main components were extracted using the correlation matrix between the variables (Shi and Harrison 1997).

PCA was used after calculating the Kaiser-Meyer-Olkin (KMO) index. Bartlett's sphericity tests were first performed to confirm the adequacy of PCA to the $\mathrm{NO}_{2}$ concentration and meteorological data. The KMO test verifies the correlation measure of the independent variables. The value of the test varies from 0 to 1 , whereas values below 0.5 indicate that the application of PCA is inappropriate. The Bartlett's test of sphericity evaluates whether the correlation matrix is an identity matrix, which would indicate that there is no data correlation, indicating that the factorial model is inappropriate.

\section{Results and discussion}

\subsection{Preliminary analysis—descriptive statistics}

The position and statistic dispersion of the $\mathrm{NO}_{2}$ tropospheric concentration data are presented in Table 2. The box-plot displaying the monthly distribution of the tropospheric $\mathrm{NO}_{2}$ concentration in the MS studied cities between 2005 and 2020 is exhibited in Fig. 2. The city of Campo Grande present as average of $\mathrm{NO}_{2}$ concentration $2.98 \times 10^{15}$ molecules/ $\mathrm{cm}^{2}$, and the median $2.87 \times 10^{15}$ molecules $/ \mathrm{cm}^{2}$. Ponta Porã, which is in the south of the State and borders Paraguay, registered higher values: $3.038 \times 10^{15}$ and $2.935 \times 10^{15} \mathrm{~mol}-$ ecules $/ \mathrm{cm}^{2}$ as average and median, respectively. Porto Murtinho, located in the west of the State of MS and on the border with Bolivia, registered the second-highest mean $3.035 \times 10^{15}$ molecules $/ \mathrm{cm}^{2}$ and median $2.814 \times 10^{15}$ molecules $/ \mathrm{cm}^{2}$. The distribution of data points over the 15 years shows that, in addition to each city being uniquely identifiable, Ponta Porã and Porto Murtinho exhibit some heavy tail properties. The resulting parameters of asymmetry and kurtosis (Skew, kurtosis) for these cities are the largest in comparison to the other studied cities.

$\mathrm{NO}_{2}$ concentrations in the State of MS indicated less seasonal amplitude among the annual averages of $0.20 \times 10^{15}$ molecules $/ \mathrm{cm}^{2}$, with higher values in July, August and September, and constant values between January and June (Fig. 2). From October to December, there is a decrease in $\mathrm{NO}_{2}$ concentration, probably due to the excessive use of power plants and domestic heating, which increase the $\mathrm{NO}_{2}$ levels during the winter. Another point is the burning of fields in the region to clean the pastures (Caúla et al. 2015; Oliveira Júnior et al. 2020).

The notch box-plot shows differences between some of the cities in their medians, since the notches do not overlap. 
Table 2 Descriptive analysis of the historical $\mathrm{NO}_{2}$ series concerning the studied cities of State MS (Campo Grande, Dourados, Três Lagoas, Corumbá, Coxim, Porto Murtinho, Ponta Porã and Chapadão do Sul) for the period from 2005 to 2020

\begin{tabular}{lllllllllll}
\hline Cities & Mean & SD & CV $(\%)$ & Minimum & Q1 & Median & Q3 & Maximum & Skewness & Kurtosis \\
\hline Campo Grande & 2.98 & 0.40 & 13.33 & 2.30 & 2.69 & 2.87 & 3.21 & 4.27 & 0.90 & 0.39 \\
Dourados & 2.99 & 0.40 & 13.47 & 2.18 & 2.69 & 2.90 & 3.24 & 4.26 & 0.73 & 0.16 \\
Três Lagoas & 2.94 & 0.40 & 13.45 & 2.11 & 2.65 & 2.87 & 3.17 & 4.41 & 0.69 & 0.23 \\
Corumbá & 2.91 & 0.70 & 24.09 & 1.96 & 2.46 & 2.64 & 3.22 & 5.56 & 1.66 & 2.56 \\
Coxim & 2.95 & 0.49 & 16.50 & 2.26 & 2.59 & 2.85 & 3.26 & 5.02 & 1.20 & 1.72 \\
Porto Murtinho & 3.04 & 0.67 & 22.19 & 1.99 & 2.56 & 2.82 & 3.36 & 6.08 & 1.46 & 2.66 \\
Ponta Porã & 3.04 & 0.51 & 16.83 & 2.10 & 2.66 & 2.94 & 3.35 & 5.61 & 1.33 & 3.08 \\
Cachoeira do Sul & 2.95 & 0.42 & 14.32 & 1.94 & 2.63 & 2.90 & 3.18 & 4.32 & 0.67 & 0.34 \\
\hline
\end{tabular}

$S D$ standard deviation, $C V$ coefficient of variation, $Q 1$ quartile $25 \%, Q 3$ quartile $75 \%$.

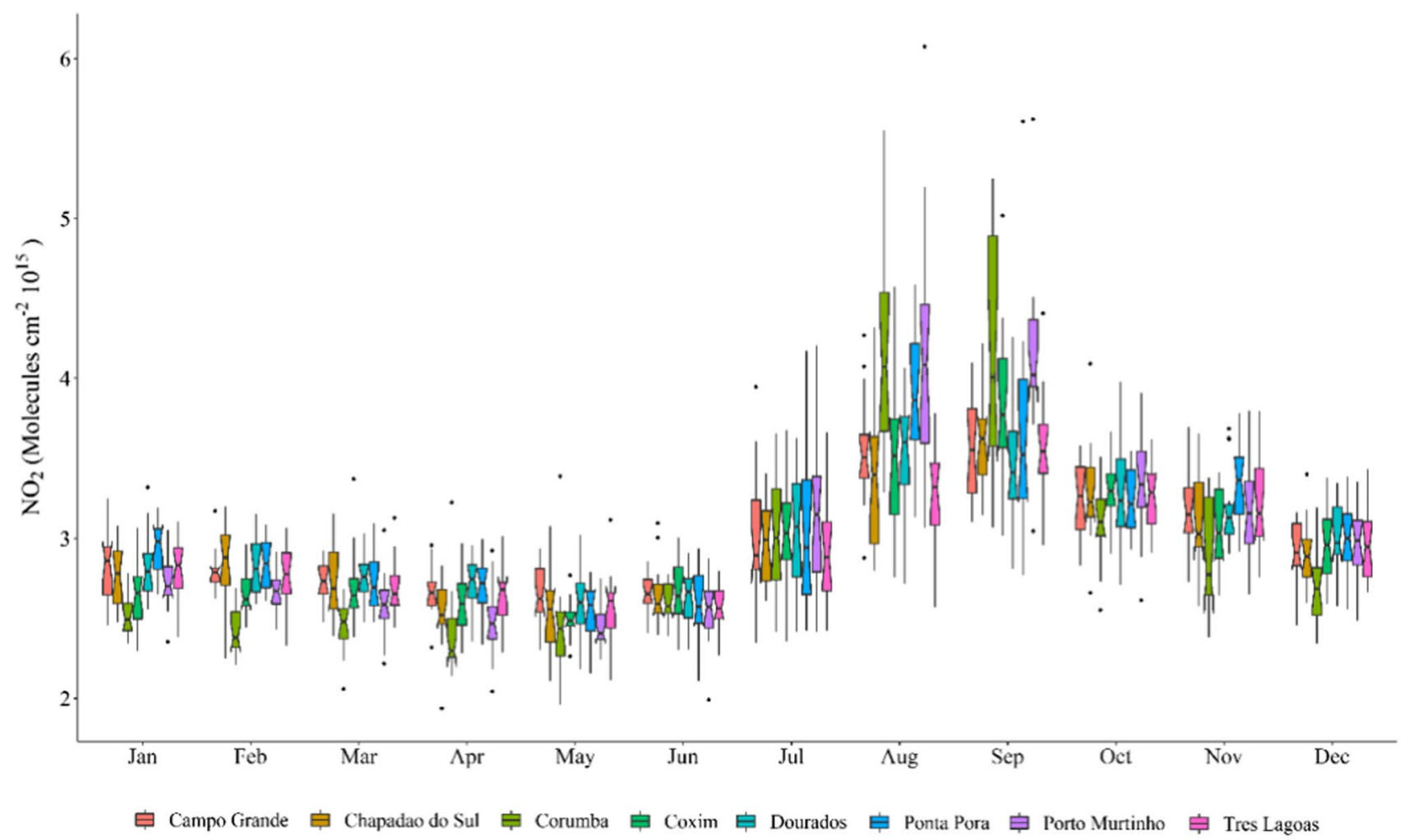

Fig. 2 Notch box-plot for monthly tropospheric $\mathrm{NO}_{2}$ concentration in cities of South Mato Grosso State, Brazil

Ponta Porã presents higher median, especially from January to August, while Dourados shows increase of the median from September to December. Both cities are located in the south portion of the MS, at the boundary between the Cerrado and the Atlantic Forest biomes, where the crops and pasture are expressive economic activities (Tomei et al. 2020). All the cities displayed a delay of one or two months in relation to the highest concentrations of $\mathrm{NO}_{2}$, from July and October relative to the driest months, from June to September (Teodoro et al. 2016; Abreu et al. 2020). Cities in the north-northwestern portions of the State of MS present lower medians. It is the case of Coxim, located in the transition between the Pantanal and the Cerrado, and Chapadão do Sul, in the Cerrado. These cities have lower crop density and lower fire foci (Oliveira-Júnior et al. 2020), which may contribute for lower concentrations of $\mathrm{NO}_{2}$. The fires are associated with the cleaning of areas for agriculture and contribute to increase the concentrations of $\mathrm{NO}_{2}$.

In contrast, the monthly behavior demonstrates similarity between the concentration of $\mathrm{NO}_{2}$ in the cities throughout the year, with a higher $\mathrm{NO}_{2}$ concentration between July and November, reaching the maximum values in August and 
September. $\mathrm{NO}_{2}$ concentrations in October begin to decrease until reaching their minimum values during April and May. This behavior is in agreement with the distribution of precipitation distribution in South Mato Grosso (Teodoro et al. 2016; Abreu et al. 2020). From December through March, the northern portion where the cities of Corumbá, Coxim, Três Lagoas, and Chapadão do Sul are located (Fig. 1) presents higher precipitated totals. From May through September, southern region where the cities of Dourados, Ponta Porã, and Porto Murtinho are located presents higher precipitated totals. From April through October, i.e., during the transition months, the influence of the orography on the larger precipitations is marked along the longitudinal direction south/northeast. This pattern indicates that $\mathrm{NO}_{2}$ concentrations are higher during dry periods in cities. The $\mathrm{NO}_{2}$ variability is linked to the meteorological conditions (UlHaq et al. 2018). Nevertheless, this pattern is not the only influence affecting the observed values of concentrations. In fact, the raining deposited by precipitation can significantly reduce the amount of pollutants in the atmosphere (Feng et al. 2001; Garrett et al. 2010; Zhao et al. 2020).

The anthropic action of using fire to clean areas for planting agricultural commodities in the rainy season (Silva Junior et al. 2020) occurs during the dry period, mainly in the months of August and September. This period precedes the rainy season, which begins in October (Teodoro et al. 2016; Abreu et al. 2020). The burning of biomass has been reported as one of the responsible factors to increase the $\mathrm{NO}_{2}$ concentrations in some periods of the year (Ossohou et al. 2019). The effect of seasonality is therefore related to anthropogenic human activities, not exclusively natural events.

\subsection{Analysis of trends in $\mathrm{NO}_{2}$ concentrations}

The analysis of the $\mathrm{NO}_{2}$ levels data series showed autocorrelation and trends for the studied period, as detected by the modified MK test. The cities of Dourados and Porto Murtinho showed decrease in $\mathrm{NO}_{2}$ concentrations, Coxim presented increase instead, considering all the monthly data exhibited in Table 3. Calculation of Sen's inclinations of significant trends indicate changes up to $\pm 0.001 \times 10^{15}$ molecules $/ \mathrm{cm}^{2}$. These trends changed approximately $1 \%$ on average. In terms of magnitude, the cities of Dourados and Porto Murtinho decreased by $0.084 \times 10^{15}$ and $0.064 \times 10^{15} \mathrm{~mol}-$ ecules $/ \mathrm{cm}^{2}$ respectively, while in Coxim, there was an increase of $0.095 \times 10^{15}$ molecules $/ \mathrm{cm}^{2}$. These results are expressed in Fig. 3 .

Additional relevant aspects about the concentrations of $\mathrm{NO}_{2}$ in the studied period are the peaks and valleys in several areas in the MS. In general, the effects of the 2008 global economic crisis can be observed during the period 2009-2011 in most of the assessed cities. Therefore,
Table 3 Result of the Mann-Kendall test for detecting trends in daily $\mathrm{NO}_{2}$ series in eight cities in South Mato Grosso

\begin{tabular}{lrlrrl}
\hline City & $Z$ & $p$ value & Tau & Sen's slope & Break point \\
\hline Campo & 0.522 & 0.601 & 0.011 & $1.27 \mathrm{E}-04-$ & - \\
$\quad$ Grande & & & & & \\
Dourados & -2.449 & $0.014^{*}$ & -0.034 & $-3.05 \mathrm{E}-04$ & Nov/2017 \\
Três Lagoas & -1.075 & 0.282 & -0.018 & $-1.77 \mathrm{E}-04$ & - \\
Corumbá & -0.225 & 0.822 & -0.004 & $-4.72 \mathrm{E}-05$ & - \\
Coxim & 4.679 & $0.000^{*}$ & 0.078 & $8.84 \mathrm{E}-04$ & $\mathrm{May} / 2013$ \\
Porto & -2.286 & $0.022^{*}$ & -0.035 & $-4.56 \mathrm{E}-04$ & Dec/2010 \\
$\quad$ Murtinho & & & & & \\
Ponta Porã & -1.75 & 0.08 & -0.027 & $-3.00 \mathrm{E}-04$ & - \\
Chapadão do & 0.063 & 0.949 & 0.001 & $6.86 \mathrm{E}-06$ & - \\
$\quad$ Sul & & & & & \\
\hline
\end{tabular}

*Within $5 \%$ level of significance

variations in the measurements during this period are associated with depletion in industrial production. The blocking measures due to COVID-19 in 2020 affected industries, transports, and other human activities in Brazil and many other countries. Therefore, emissions of air pollutants during the pandemic have been drastically reduced in several countries (Zhang et al. 2021; Wang et al. 2021). In Brazil, the impact of COVID-19 containment actions in terms of air pollutants is still being evaluated. In this study, reductions of the averaged $\mathrm{NO}_{2}$ concentrations have been observed during 2020 compared to the period from 2005 to 2019 in only two cities, Dourados and Três Lagoas, in the order of $0.02 \times 10^{15}$ and $0.03 \times 10^{15}$ molecules $/ \mathrm{cm}^{2}$. In the other studied cities, higher concentrations of $\mathrm{NO}_{2}$ have been observed during 2020 , with an average of $0.01 \times 10^{15}$ to $0.22 \times 10^{15}$ molecules $/ \mathrm{cm}^{2}$, see Table 4 . Therefore, although for some months of 2020, the concentration of $\mathrm{NO}_{2}$ was lower, in general it was higher compared to the period from 2005 to 2019 . These results suggest the general non-commitment of the containment values during the pandemic in Brazil, which may have contributed to the excessive number of deaths, since the relationship between COVID-19 and its mortality with the concentration of $\mathrm{NO}_{2}$ in the atmosphere has been evidenced. The concentration of $\mathrm{NO}_{2}$ as a precursor to the formation of secondary particulate material may favor COVID-19 and make the respiratory system more susceptible to this infection (Mele et al. 2021).

Figure 4 shows the monthly dispersion of $\mathrm{NO}_{2}$ concentration as a function of time in years, and the regression curves where most of the cases can be observed. The MK test for the monthly data series shows some trends for specific months. In addition, during the dry period in MS, which is from April to October, some relevant trends have been detected. Increase trends are observed for Corumbá in July and for Coxim in July, August, and December. These cities are located in the driest area of South Mato Grosso 

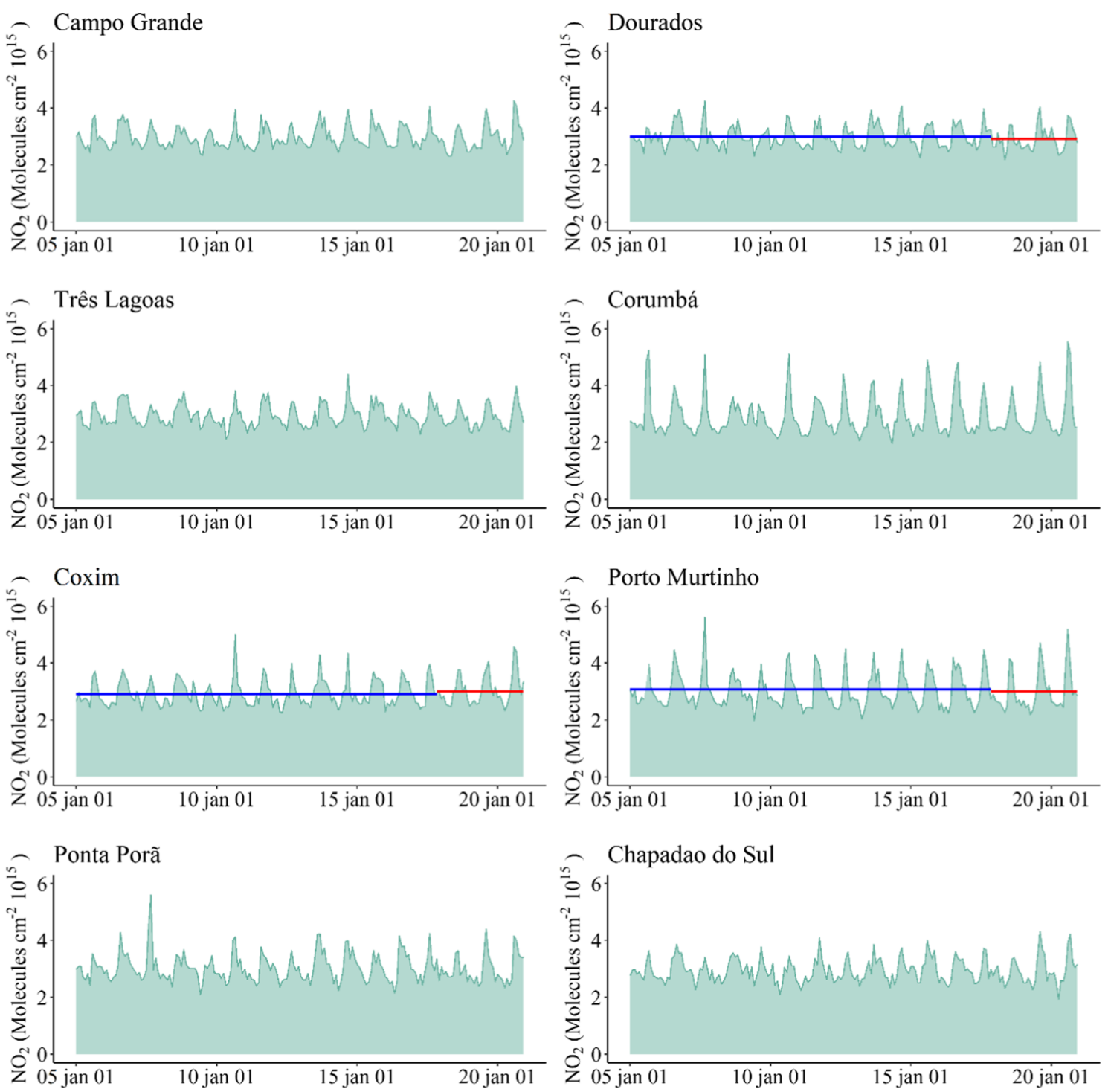

Fig. 3 Time series of $\mathrm{NO}_{2}$ concentration in the eight cities of South Mato Grosso. The blue line represents the mean before and the red line the mean after the break point of the series

(Abreu et al. 2020) and in the Pantanal biome. The exception is Chapadão do Sul that is located in the Cerrado biome. Oliveira-Junior et al. (2020) detected higher occurrence of fire foci in relation to the Cerrado and the Atlantic Forest areas. Decrease trends have been observed for Corumbá in January, for Dourados in May, and for Porto Murtinho in April and May.

With the exception of Chapadão do Sul, the decreasing trends in the $\mathrm{NO}_{2}$ concentrations during April and May may be associated with the characteristics of precipitation in the southern region of the state, in which there are higher total precipitates (Abreu et al. 2020). There is a noticeable relationship connecting the environmental impact of agricultural expansion and fires to the $\mathrm{NO}_{2}$ concentrations. Although few trends have been detected, they occurred in months of area cleaning activities with the use of fires that result in large emissions of gasses, include $\mathrm{NO}_{\mathrm{x}}$, which contribute to increase the greenhouse gas emissions and global warming (Oliveira-Junior et al. 2020).

Table 5 shows the MK test results, Tau, Sen's slope, and the break point, i.e., the year of change by the Pettitt test validating a significant trend in MK test. The changes indicated an increase of $\mathrm{NO}_{2}$ concentration between $0.03 \times 10^{15}$ and $0.070 \times 10^{15}$ molecules $/ \mathrm{cm}^{2}$, especially in drier months for cities in the south of the State of MS. The decrease of values varied between $0.02 \times 10^{15}$ and $0.04 \times 10^{15}$ molecules/ $\mathrm{cm}^{2}$. The break points in the monthly series occurred from 2010 to 2014, i.e., from the first to the third quartile of the data series. 
Table 4 Monthly and annual average of concentration of $\mathrm{NO}_{2}$ in the refereed cities of South Mato Grosso, Brazil from 2005 to 2019 and 2020

\begin{tabular}{|c|c|c|c|c|c|c|c|c|c|}
\hline Period & Month & Campo Grande & Dourados & Três Lagoas & Corumbá & Coxim & Porto Murtinho & Ponta Porã & $\begin{array}{l}\text { Cha- } \\
\text { padão do } \\
\text { Sul }\end{array}$ \\
\hline \multirow[t]{12}{*}{$2005-2019$} & Jan & 2.80 & 2.79 & 2.82 & 2.52 & 2.64 & 2.75 & 2.95 & 2.75 \\
\hline & Feb & 2.79 & 2.83 & 2.74 & 2.42 & 2.65 & 2.68 & 2.85 & 2.85 \\
\hline & Mar & 2.73 & 2.75 & 2.72 & 2.46 & 2.69 & 2.59 & 2.73 & 2.74 \\
\hline & Apr & 2.65 & 2.73 & 2.65 & 2.41 & 2.60 & 2.47 & 2.71 & 2.58 \\
\hline & May & 2.65 & 2.62 & 2.59 & 2.45 & 2.49 & 2.44 & 2.52 & 2.55 \\
\hline & Jun & 2.67 & 2.65 & 2.58 & 2.59 & 2.65 & 2.56 & 2.60 & 2.64 \\
\hline & Jul & 3.05 & 3.05 & 2.91 & 3.00 & 3.00 & 3.14 & 3.05 & 2.98 \\
\hline & Aug & 3.50 & 3.55 & 3.25 & 4.06 & 3.43 & 4.08 & 3.86 & 3.36 \\
\hline & Sep & 3.51 & 3.43 & 3.53 & 4.09 & 3.83 & 4.15 & 3.65 & 3.56 \\
\hline & Oct & 3.21 & 3.25 & 3.24 & 3.11 & 3.28 & 3.38 & 3.22 & 3.29 \\
\hline & Nov & 3.17 & 3.19 & 3.25 & 2.91 & 3.06 & 3.15 & 3.35 & 3.11 \\
\hline & Dec & 2.93 & 3.02 & 2.98 & 2.71 & 2.94 & 2.98 & 2.95 & 2.90 \\
\hline \multirow[t]{12}{*}{2020} & Jan & 3.25 & 3.32 & 2.82 & 2.44 & 2.78 & 2.64 & 2.82 & 2.80 \\
\hline & Feb & 2.80 & 2.95 & 2.80 & 2.38 & 2.84 & 2.60 & 2.70 & 2.87 \\
\hline & Mar & 2.67 & 2.76 & 2.44 & 2.44 & 2.63 & 2.50 & 2.62 & 2.57 \\
\hline & Apr & 2.96 & 2.35 & 2.52 & 2.23 & 2.32 & 2.51 & 2.33 & 1.94 \\
\hline & May & 2.37 & 2.40 & 2.42 & 2.30 & 2.51 & 2.59 & 2.66 & 2.60 \\
\hline & Jun & 2.59 & 2.50 & 2.37 & 2.78 & 2.81 & 2.44 & 2.41 & 2.56 \\
\hline & Jul & 2.76 & 2.80 & 2.94 & 3.56 & 3.42 & 4.07 & 2.64 & 2.94 \\
\hline & Aug & 4.27 & 3.75 & 3.47 & 5.55 & 4.57 & 5.20 & 4.17 & 3.91 \\
\hline & Sep & 4.09 & 3.66 & 3.98 & 5.10 & 4.38 & 3.89 & 3.99 & 4.22 \\
\hline & Oct & 3.35 & 3.29 & 3.31 & 3.02 & 3.32 & 2.88 & 3.47 & 3.23 \\
\hline & Nov & 3.31 & 3.12 & 3.11 & 2.54 & 2.88 & 3.00 & 3.40 & 3.05 \\
\hline & Dec & 2.87 & 2.77 & 2.68 & 2.54 & 3.38 & 2.84 & 3.38 & 3.17 \\
\hline \multirow[t]{2}{*}{ Annual average } & 2005-2019 & 2.97 & 2.99 & 2.94 & 2.90 & 2.94 & $\mathbf{3 . 0 3}$ & 3.04 & 2.94 \\
\hline & 2020 & 3.11 & 2.97 & 2.90 & 3.07 & 3.15 & 3.10 & 3.05 & 2.99 \\
\hline
\end{tabular}

Numbers in red indicate lower concentrations of $\mathrm{NO}_{2}$ in comparison to 2020, with the average values obtained for the period from 2005 to 2019

\subsection{Annual modeling of $\mathrm{NO}_{2}$ concentration as a function of meteorological parameters}

Table 6 presents the following parameters of the PCA adjustment: the KMO index, $p$ value of the sphericity test, explained variance, and the eigenvalues of the first two main components, which are $\mathrm{PC} 1$ and $\mathrm{PC} 2$, respectively. The values of KMO are greater than 0.5, except for Ponta Porã and Dourados, and $p$ values for Bartlett's sphericity test are less than 0.05 , that suggest there is substantial correlation in the data. Hence, data are appropriate for applying PCA. Figure 5 shows individual variables from the output of the PCA analysis. The first main component, for all cities, is able to explain percentages ranging between 51 and 57, while the second component explains percentages ranging between 35 and $47 \%$ of the data variance. Therefore, the first two main components can explain a percentage greater than $89 \%$ of the data variance. In PC1, for all cities, eigenvectors were positive for $\mathrm{NO}_{2}$ and negative for Prec and RH. $T_{\max }$ and
$T_{\min }$ were positive for four cities: Dourados, Corumbá, Ponta Porã and Chapadão do Sul, and negative for four others: Campo Grande, Três Lagoas, Coxim and Porto Murtinho.

Overall, the eigenvectors are elevated for all variables, indicating that $\mathrm{PC} 1$ is an overview of the relationship between meteorological variables and $\mathrm{NO}_{2}$ concentration, in which the higher the $\mathrm{RH}$ and Prec, the lower the $\mathrm{NO}_{2}$ concentrations. The role of temperature is ambiguous, indicating that in cities where these variables had positive/ negative eigenvectors, the highest temperatures are associated with the highest/lowest concentrations of $\mathrm{NO}_{2}$. Higher scores indicate places with higher concentrations of $\mathrm{NO}_{2}$, lower precipitations and relative humidity. These results also reaffirm the seasonal factor of $\mathrm{NO}_{2}$ concentrations, which are mainly related to humid climatic conditions (Hua et al. 2021). The scores are higher from July through August, the driest months of the year. The higher temperatures and $\mathrm{RH}$ in the atmosphere, which occur during summers in MS, are typically beneficial for the removal of $\mathrm{NO}_{2}$ through 
Fig. 4 Dispersion of $\mathrm{NO}_{2}$ concentration for eight cities of South Mato Grosso in function of the years and the consequent regression lines
Table 5 Mann-Kendall results for relevant months and cities of South Mato Grosso, Tau value, Sen's slope, and year of break of time series of $\mathrm{NO}_{2}$ concentration
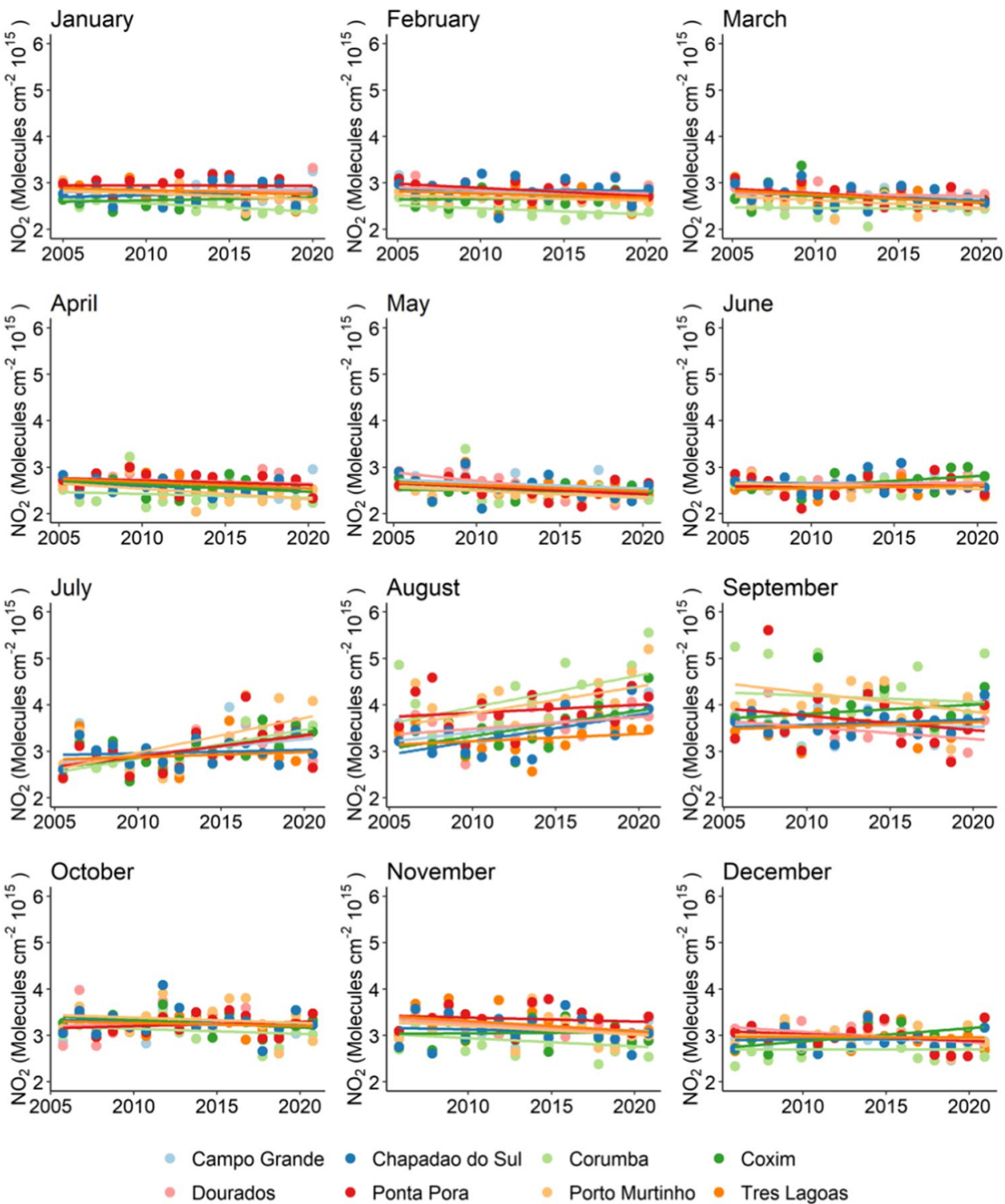

\begin{tabular}{llrlrrl}
\hline City & Month & \multicolumn{1}{l}{ Z MK } & $p$ value & \multicolumn{1}{l}{ Tau } & Sen’s slope & Break point \\
\hline South Chapadão & May & -4.4421 & 0.0000 & -0.2667 & -0.0205 & 2014 \\
Corumbá & Jan & -7.1104 & 0.0170 & -0.4500 & -0.0161 & 2012 \\
Corumbá & Jul & 6.3798 & 0.0034 & 0.5500 & 0.0697 & 2014 \\
Coxim & Jul & 5.9227 & 0.0170 & 0.4500 & 0.0508 & 2012 \\
Coxim & Aug & 3.0529 & 0.0217 & 0.4333 & 0.0399 & 2014 \\
Coxim & Dec & 6.3102 & 0.0170 & 0.4500 & 0.0326 & 2010 \\
Dourados & May & -9.4450 & 0.0005 & -0.6500 & -0.0373 & 2012 \\
Ponta Porã & Feb & -6.2314 & 0.0428 & -0.3833 & -0.0197 & 2012 \\
Porto Murtinho & Apr & -5.2228 & 0.0000 & -0.3167 & -0.0226 & 2010 \\
Porto Murtinho & May & -3.9239 & 0.0001 & -0.3500 & -0.0148 & 2011 \\
\hline
\end{tabular}




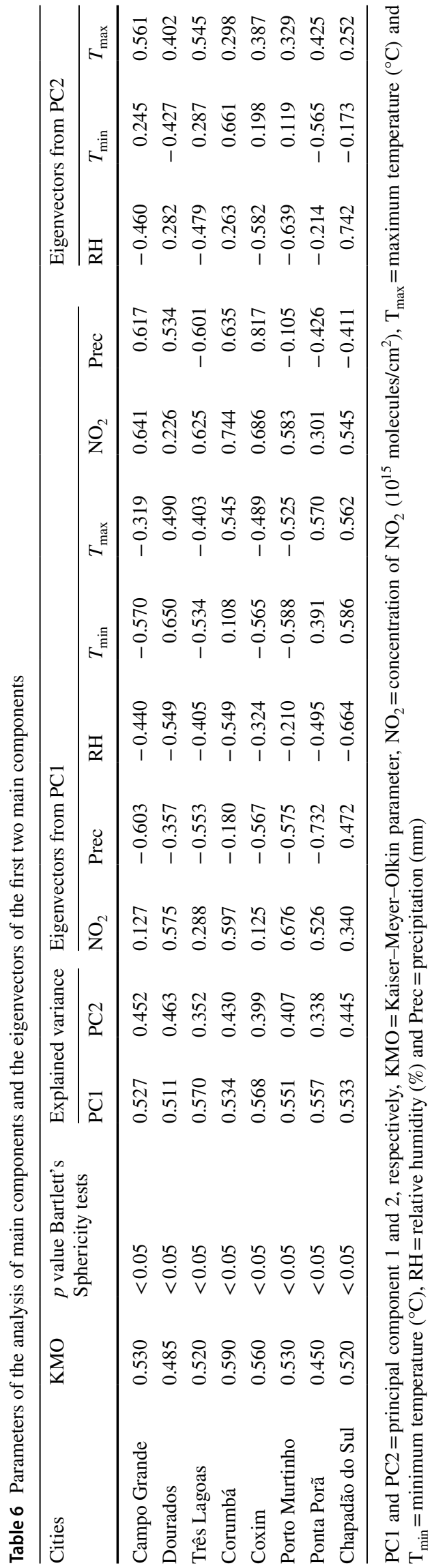

Photolysis (Feng et al. 2001; Dong et al. 2009). Nevertheless, at some cities (Dourados, Corumbá, Ponta Porã and Chapadão do Sul, the lower temperatures would be allied with lower concentrations of $\mathrm{NO}_{2}$.

PC2 also originated higher eigenvectors for almost all variables in all cities varying its pattern among cities, i.e., presenting positive and negative eigenvector values. In general, this component indicates the driest months with the highest scores and the most humid months with the lowest scores. Its eigenvectors for $\mathrm{NO}_{2}$ is always positive. Thus, $\mathrm{PC} 2$ indicates differences in the dynamics of $\mathrm{NO}_{2}$ throughout the atmosphere of every region of MS. Generally, moisture and precipitation are $\mathrm{NO}_{2}$ dispersing agents (Cai et al. 2018), as well as high temperatures cause $\mathrm{NO}_{2}$ photolysis, reducing its concentration (Feng et al. 2001; Dong et al. 2009).

The correlation of meteorological elements with the concentration of atmospheric $\mathrm{NO}_{2}$ can be modeled using the multivariate data technique, represented by the eigenvectors of Table 6 , avoiding multi-collinearity in regression models that would include several factors correlated not merely with their response of variable $\mathrm{NO}_{2}$, but also to each other through weather variables. Therefore, it is possible to estimate meteorological patterns and to establish scores for each month through meteorological variables, by recognizing higher concentrations of atmospheric $\mathrm{NO}_{2}$.

\section{Conclusion}

Both the satellite and the terrestrial $\mathrm{NO}_{2}$ data sets of measurements for MS-Brazil from 2005 to 2020 present basic levels during the rainy season, which occurs from October and March, and maximum levels during the dry season from April to August. The study shows high relative humidity in the MS from October to March, which contributes to the removal of pollutants such as $\mathrm{NO}_{2}$. Temperature is also an important factor during a few hours due to the photochemical effect that produce $\mathrm{OH}$ radicals, which reacts with $\mathrm{NO}_{2}$ causing it to sink in terms of $\mathrm{HNO}_{3}$. Climatic seasonality is, therefore, an influencing factor in the atmospheric specifications of $\mathrm{NO}_{2}$.

Additionally, biomass-burning activities, especially during the driest period of the year, contribute to the increase of atmospheric pressure followed by an increase of $\mathrm{NO}_{2}$ concentration. Burning of areas for cleaning and subsequent implantation of agricultural crops is notable in South Mato Grosso. Even during the COVID-19 pandemic, the levels of pollutant were similar to those of previous years, with the exception of months in which there were more important restrictions of commercial and industrial activities. The largest tropospheric and total $\mathrm{NO}_{2}$ concentrations occurred in industrialized and highly agglomerated regions. The highest 
Fig. 5 Individual variables from the output of Principal Component Analysis (ACP) of the cities of South Mato Grosso
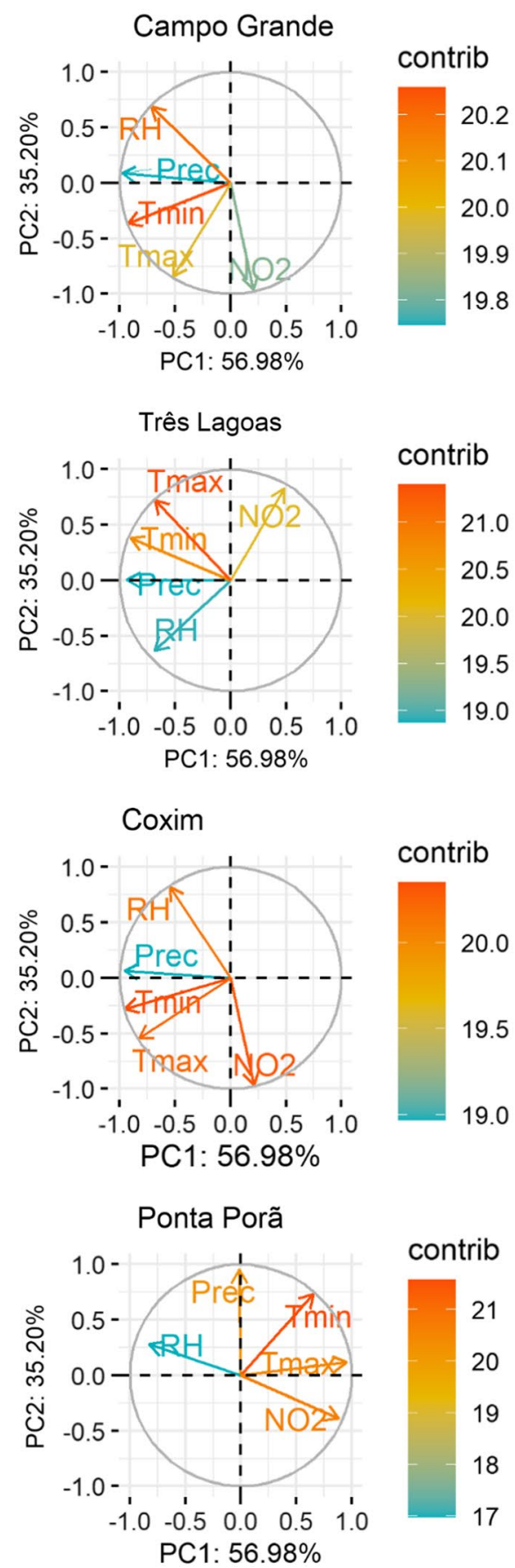
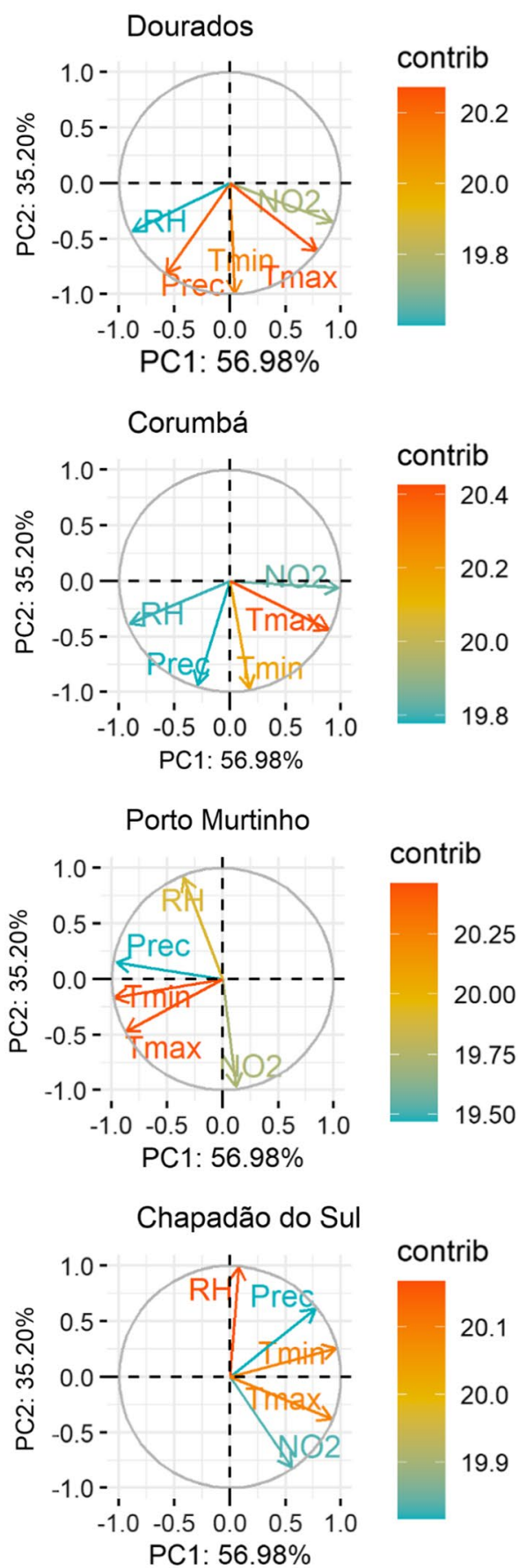

$\mathrm{NO}_{2}$ rules were also observed in biomass burning regions, the trend is not explained as a whole. They reflect differences in trends of variations due to anthropogenic connections of $\mathrm{NO}_{x}$ in the regions.

It has been investigated stationarity in the regional $\mathrm{NO}_{2}$ column time series and some trends have been found. It is especially noteworthy that trends of increasing $\mathrm{NO}_{2}$ concentration occur in drier months of the year at some cities. The results demonstrate that the $\mathrm{NO}_{2}$ of the tropospheric column increased by around 3\% and the breaking point of the series varied from 2010 to 2014.

This study successfully produced the analysis of the vertical column of tropospheric $\mathrm{NO}_{2}$ with values that are smooth and consistent in terms of space and time. A multivariate approach using eigenvectors to predict the $\mathrm{NO}_{2}$ rules has been applied. The main components within $89 \%$ variance of the explained data and the eigenvectors are coherent to climatic seasonality and the mandatory application of $\mathrm{NO}_{2}$. 
Satellite data can be used to assess spatial and temporal variations of $\mathrm{NO}_{2}$. The integration of satellite inclusion with terrestrial data provides an overview of $\mathrm{NO}_{2}$ in the atmosphere, which is an essential tool for quality managers and politicians to understand the spatial distribution of air quantities to define air quality policy and mitigation plan for South Mato Grosso.

Supplementary Information The online version contains supplementary material available at https://doi.org/10.1007/s00703-021-00855-5.

Acknowledgements The authors would like to thank the universities for their support. F. Aristone thanks the $\mathrm{CNPq}-\mathrm{Brazil}$ for financial support.

Author contributions All authors participated in the preparation of the review and writing of the project, data collection, data analysis and writing of the article, review and writing of the article and review of the article.

Funding This study was funded by cnpq (309681/2019-7).

Data availability This research was supported by the Universities and by the UFMS Air Quality Laboratory. We would like to acknowledge the use of data from the tropospheric $\mathrm{NO}_{2}$ column at http://aura.gsfc. nasa.gov/lindex.html.

\section{Declarations}

Conflict of interest The authors declare no conflicts of interest.

\section{References}

Abreu MC, Souza A, Lyra GB, Pobocikova I, Cecílio RA (2020) Analysis of monthly and annual rainfall variability using linear models in the state of South Mato Grosso, Midwest of Brazil. Int J Climatol 41:E2445-E2461. https://doi.org/10.1002/joc.6857

Alvares CA, Stape JL, Sentelhas PC, Gonçalves JLM, Sparovek G (2013) Köppen's climate classification map for Brazil. Meteorol Z 22:711-728. https://doi.org/10.1127/0941-2948/2013/0507

Burn DH, Mansour R, Zang K, Whitfield PH (2011) Trends and Variability in Extreme Rainfall Events in British Columbia, Canadian Water Resources Journal / Revue canadienne des ressources hydriques 36(1):67-82. https://doi.org/10.4296/cwrj3601067

Cai K, Zhang Q, Li S, Li Y, Ge W (2018) Spatial-temporal variations in $\mathrm{NO}_{2}$ and $\mathrm{PM}_{2.5}$ over the Chengdu-Chongqing Economic Zone in China during 2005-2015 based on satellite remote sensing. Sensors 18:3950. https://doi.org/10.3390/s18113950

Castellanos P, Boersma KF (2012) Reductions in nitrogen oxides over Europe driven by environ- mental policy and economic recession. Sci Rep 2:1-7. https://doi.org/10.1038/srep00265

Caúla RH, Oliveira-Júnior JF, Lyra GB, Delgado RC, Heilbron Filho PFL (2015) Overview of fire foci causes and locations in Brazil based on meteorological satellite data from 1998 to 2011. Environ Earth Sci 74:1497-1508. https://doi.org/10.1007/ s12665-015-4142-z

Dobber MR, Dirksen RJ, Levelt PF, van den Oord GH, Voors RH, Kleipool Q, \& Rozemeijer NC (2006). Ozone monitoring instrument calibration. IEEE Transactions on Geoscience and remote
Sensing, 44(5):1209-1238. https://doi.org/10.1109/TGRS.2006. 869987

Dong J, Wang S, Shang K (2009) Influence of precipitation on air quality in several cities of China. J Arid Land Resour Environ 23:43-48

Drosoglou T, Koukouli ME, Kouremeti N, Bais AF, Zyrichidou I, Balis D, Van der ARJ, Xu J, Li A (2018) MAX-DOAS NO observations over Guangzhou, China; ground-based and satellite comparisons. Atmos Meas Tech 11:2239-2255. https://doi. org/10.5194/amt-11-2239-2018

Duncan BN, Yoshida Y, Foy B, Lamsal LN, Streets DG (2013) The observed response of Ozone Monitoring Instrument (OMI) $\mathrm{NO}_{2}$ columns to $\mathrm{NO}_{x}$ emission controls on power plants in the United States: 2005-2011. Atmos Environ 81:102-111. https://doi.org/ 10.1016/j.atmosenv.2013.08.068

Fan H, Zhao C, Yang Y (2020) A comprehensive analysis of the spatio-temporal variation of urban air pollution in China during 2014-2018. Atmos Environ 20:117066. https://doi.org/10. 1016/j.atmosenv.2019.117066

Fan H, Wang Y, Zhao C, Yang Y, Yang X, Sun Y, Jiang S (2021) The role of primary emission and transboundary transport in the air quality changes during and after the COVID-19 lockdown in China. Geophys Res Lett 48:e2020GL091065. https://doi.org/ 10.1029/2020GL091065

Fantozzi F, Monaci F, Blanusa T, Bargagli R (2015) Spatio-temporal variations of ozone and nitrogen dioxide concentrations under urban trees and in a nearby open area. Urban Clim 12:119-127. https://doi.org/10.1016/j.uclim.2015.02.001

Feng ZW, Huang YZ, Feng YW, Ogura N, Zhang FZ (2001) Chemical composition of precipitation in Beijing area, Northern China. Water Air Soil Pollut 125:345-356. https://doi.org/10. 1023/A: 1005287102786

Garrett TJ, Chuanfeng ZC, Novelli PC (2010) Assessing the relative contributions of transport efficiency and scavenging to seasonal variability in Arctic aerosol. Tellus 62B:190-196. https://doi. org/10.1111/j.1600-0889.2010.00453.x

Grajales FJ, Baquero-Bernal A (2014) Inference of surface concentrations of nitrogen dioxide $\left(\mathrm{NO}_{2}\right)$ in Colombia from tropospheric columns of the ozone measurement instrument (OMI). Atmósfera 27:193-214. https://doi.org/10.1016/S0187-6236(14) $71110-5$

Griffin D, Zhao X, McLinden CA, Boersma F, Bourassa A, Dammers E, Degenstein D, Eskes H, Fehr L, Fioletov V, Wolde M (2018) High resolution mapping of nitrogen dioxide with TROPOMI: first results and validation over the Canadian oil sands. Geophys Res Lett 46:1049-1060. https://doi.org/10.1029/2018GL081095

Hagenbjörk A, Malmqvist E, Mattisson K, Sommar NJ, Modig L (2017) The spatial variation of $\mathrm{O}_{3}, \mathrm{NO}, \mathrm{NO}_{2}$ and $\mathrm{NO}_{x}$ and the relation between them in two Swedish cities. Environ Monit Assess 189:161. https://doi.org/10.1007/s10661-017-5872-Z

Hua J, Zhang Y, Foy B, Shang J, Schauer JJ, Mei X, Sulaymon ID, Han T (2021) Quantitative estimation of meteorological impacts and the COVID-19 lockdown reductions on $\mathrm{NO}_{2}$ and $\mathrm{PM}_{2.5}$ over the Beijing area using Generalized Additive Models (GAM). J Environ Manage 291:112676. https://doi.org/10.1016/j.jenvman. 2021.112676

Irie H, Muto T, Itahashi S, Kurokawa JI, Uno I (2016) Turnaround of tropospheric nitrogen di-oxide pollution trends in China, Japan, and South Korea. Sola 12:170-174. https://doi.org/10.2151/sola. 2016-035

Jiang S, Zhao C, Fan H (2021) Toward understanding the variation of air quality based on a comprehensive analysis in hebei province under the influence of COVID-19 lockdown. Atmosphere 12:267. https://doi.org/10.3390/atmos12020267

Kendall MG (1975) Rank correlation methods. Griffin, London, p 272 
Kengni L, Mboussop AN, Kopa AN, Tankou CM, Tematio P, Ngoupayou JRN (2019) Rainfall variability on the southern slope of the Bambouto mountain (West-Cameroon) and impact on the crop cultivation calendar. Journal of African Earth Sciences 154:164-171. https://doi.org/10.1016/j.jafrearsci.2019.03.020

Khokhar MF, Yasmin N, Fatima N, Beirle S, Wagner T (2015) Detection of trends and seasonal variation in tropospheric nitrogen dioxide over Pakistan. Aerosol Air Qual Res 15:2508-2524. https://doi.org/10.4209/aaqr.2015.03.0157

Lamsal LN, Martin RV, Donkelaar AV, Celarier EA, Buscela EJ, Boersma KF, Dirksen R, Luo C, Wang Y (2010) Indirect validation of tropospheric nitrogen dioxide retrieved from the OMI satellite instrument: insight into the seasonal variation of nitrogen oxides at northern Midlatitudes. J Geo Res 115:458-473. https://doi.org/10.1029/2009JD013351

Lelieveld J, Beirle S, Hörmann C, Stenchikov G, Wagner T (2015) Abrupt recent trend changes in atmospheric nitrogen dioxide over the Middle East. Sci Adv 1:e1500498. https://doi.org/10. $1126 /$ sciadv. 1500498

Levelt PF, Oord GHJVG, Dobber MR (2006) The ozone monitoring instrument. IEEE T Geosci Remote Sens 44:1093-1101

Mann HB (1945) Nonparametric tests against trend. Econometrica J. Econometr. Soc. 13:245-259. https://doi.org/10.2307/1907187

Mele M, Magazzino C, Scheneider N, Strezov V (2021) $\mathrm{NO}_{2}$ levels as a contributing factor to COVID-19 deaths: the first empirical estimate of threshold values. Environ Res 194:110663. https:// doi.org/10.1016/j.envres.2020.110663

Nakada LYK, Urban RC (2020) COVID-19 pandemic: impacts on the air quality during the partial lockdown in São Paulo state, Brazil. Sci Total Environ 730:139087. https://doi.org/10.1016/j. scitotenv.2020.139087

Oliveira Júnior JF, Teodoro PE, Silva Junior CA, Baio FHR, Gava R, Capristo-Silva GF, Gois G, Correia Filho WLF, Lima M, Santiago DB, Freitas WK, Santos PJ, Costa MS (2020) Fire foci related to rainfall and biomes of the state of South Mato Grosso, Brazil. Agric Meteorol 282-283:107861. https://doi. org/10.1016/j.agrformet.2019.107861

Ossohou M, Galy-Lacaux C, Yoboué V, Hickman JE, Gardrat E, Adon M, Darras A, Laouali D, Akpo A, Diop B, Opepa C (2019) Trends and seasonal variability of atmospheric $\mathrm{NO}_{2}$ and $\mathrm{HNO}_{3}$ concentrations across three major African biomes inferred from long-term series of ground-based and satellite measurements. Atmos Environ 207:148-166. https://doi.org/10. 1016/j.atmosenv.2019.03.027

Pettitt AN (1979) A non-parametric approach to the change-point problem. J R Stat Soc Series C (appl Stat) 28:126-135. https:// doi.org/10.2307/2346729

Richter A, Burrows JP, Nüß H, Granier C, Niemeier U (2005) Increase in tropospheric nitrogen dioxide over China observed from space. Nature 437:129-132. https://doi.org/10.1038/natur e04092

Sa' adi Z, Shahid S, Ismail T, Chung ES, Wang XJ (2019) Trends analysis of rainfall and rainfall extremes in Sarawak, Malaysia using modified Mann-Kendall test. Meteorol Atmos Phys 131:263-277. https://doi.org/10.1007/s00703-017-0564-3

Schneider P, Van der ARJ (2012) A global single-sensor analysis of 2002-2011 tropospheric nitrogen dioxide trends observed from space. J Geophys Res: Atmos 117(D16):1-17. https://doi.org/10. 1029/2012JD017571

Sen PK (1968) Estimates of the regression coefficient based on Kendall's tau. J Am Stat Assoc 63:1379-1389

Shi JP, Harrison RM (1997) Regression modelling of hourly $\mathrm{NO}_{x}$ and $\mathrm{NO}_{2}$ concentrations in urban air in London. Atmos Environ 31:4081-4094. https://doi.org/10.1016/S1352-2310(97)00282-3

Silva Junior CA, Teodoro PE, Delgado RC, Teodoro LPR, Lima M, Pantaleão AA, Baio FHR, Azevedo GB, Azevedo GTOS,
Capristo-Silva GF, Arvor D, Facco CU (2020) Persistent fire foci in all biomes undermine the Paris Agreement in Brazil. Sci Rep 10:16246. https://doi.org/10.1038/s41598-020-72571-w

Souza A, Fernandes WA, Albrez EA, Galvíncio JD (2012) Análise de Agrupamento da Precipitação e da Temperatura no South Mato Grosso. Acta Geo 6:109-124. https://doi.org/10.5654/acta.v6i12. 782

Souza A, Aristone F, Garcia AP, Santos DA, Nóbrega S (2018a) Estudo da associação entre óxidos de nitrogênio e concentração de ozônio com parâmetros meteorológicos. Geosul 33:164-183. https://doi. org/10.5007/2177-5230.2018v33n68p164

Souza A, Ikefuti PV, Garcia AP, Santos DAS, Oliveira S (2018b) Análise da Relação Entre $\mathrm{O}_{3}, \mathrm{NO}$ e $\mathrm{NO}_{2}$ Usando Técnicas de Regressão Linear Múltipla. Geograph 20:124. https://doi.org/10. 22409/GEOgraphia2018.v20i43.a27215

Teodoro PE, Oliveira-Júnior JF, Cunha ER, Correa CCG, Torres FE, Bacani VM, Gois G, Ribeiro LP (2016) Cluster analysis applied to the spatial and temporal variability of monthly rainfall in South Mato Grosso State, Brazil. Meteorol Atmos Phys 128:197-209. https://doi.org/10.1007/s00703-015-0408-y

Tomei J, Lyrio de Oliveira L, Oliveira Ribeiro C, Lee Ho L, Montoya LG (2020) Assessing the relationship between sugarcane expansion and human development at the municipal level: a case study of South Mato Grosso, Brazil. Bio Bioener 141:105700. https:// doi.org/10.1016/j.biombioe.2020.105700

Torres O, Ahn C, Chen Z (2013) Improvements to the OMI near-UV aerosol algorithm using A-train CALIOP and AIRS observations. Atmos Meas Tech 6:3257-3270. https://doi.org/10.5194/ amt-6-3257-2013

Ul-Haq Z, Rana AD, Tariq S, Mahmood K, Ali M, Bashir I (2018) Modeling of tropospheric $\mathrm{NO}_{2}$ column over different climatic zones and land use/land cover types in South Asia. J Atmos Sol Ter Phys 168:80-99. https://doi.org/10.1016/j.jastp.2018.01.022

Uliana EM, Silva DD, Uliana EM, Rodrigues BS, Corrêdo LP (2015) Análise de tendência em séries históricas de vazão e precipitação: uso de teste estatístico não paramétrico. Rev Ambient Água 10:82-88. https://doi.org/10.4136/ambi-agua.1427

Wang Z, Uno I, Yumimoto K, Itahashi S, Chen X, Yang W, Wang Z (2021) Impacts of COVID-19 lockdown, Spring Festival and meteorology on the $\mathrm{NO}_{2}$ variations in early 2020 over China based on in-situ observations, satellite retrievals and model simulations. Atmos Environ 244:117972. https://doi.org/10.1016/j.atmosenv. 2020.117972

Xiao K, Wang Y, Wu G, Fu B, Zhu Y (2018) Spatiotemporal characteristics of air pollutants $\left(\mathrm{PM}_{10}, \mathrm{PM}_{2.5}, \mathrm{SO}_{2}, \mathrm{NO}_{2}, \mathrm{O}_{3}\right.$, and $\left.\mathrm{CO}\right)$ in the inland basin city of Chengdu, Southwest China. Atmosphere 9:74-90. https://doi.org/10.3390/atmos9020074

Xue R, Wang S, Li D, Zou Z, Chan KL, Valks P, Saiz-Lopez A, Zhou $\mathrm{B}$ (2020) Spatio-temporal variations in $\mathrm{NO}_{2}$ and $\mathrm{SO}_{2}$ over Shanghai and Chongming Eco-Island measured by Ozone Monitoring Instrument (OMI) during 2008-2017. J Clean Prod 258:120563. https://doi.org/10.1016/j.jclepro.2020.120563

Yanfang H, Litao W, Yi Z, Shixin W, Cong D, Feng W (2019) Spatiotemporal variations of tropospheric column nitrogen dioxide over Jing-Jin-Ji during the past decade. Int J Remote Sens 40:15-30. https://doi.org/10.1080/01431161.2018.1463115

Yavaşlı DD (2020) Spatio-temporal Variations of tropospheric nitrogen dioxide in Turkey based on satellite remote sensing. Geo Pan 24:168-175. https://doi.org/10.5937/gp24-25482

Yue S, Wang C (2004) The Mann-Kendall test modified by effective sample size to detect trend in serially correlated hydrological series. Water Resour Manag 18:201-218. https://doi.org/10. 1023/B:WARM.0000043140.61082.60

Zeri M, Oliveira-Júnior JF, Lyra GB (2011) Spatiotemporal analysis of particulate matter, sulfur dioxide and carbon 
monoxide concentrations over the city of Rio de Janeiro, Brazil. Meteorol Atmos Phys 113:139-152. https://doi.org/10.1007/ s00703-011-0153-9

Zeri M, Carvalho VSB, Cunha-Zeri G, Oliveira-Júnior JF, Lyra GB, Freitas ED (2016) Assessment of the variability of pollutants concentration over the metropolitan area of São Paulo, Brazil, using the wavelet transform. Atmos Sci Lett 17:87-95. https://doi.org/ 10.1002/asl.618

Zhang Y, Ma Z, Gao Y, Zhang M (2021) Impacts of the meteorological condition versus emissions reduction on the PM2.5 concentration over Beijing-Tianjin-Hebei during the COVID-19 lockdown. Atmos. Oceanic Sci. Lett. 14:100014. https://doi.org/10.1016/j. aosl.2020.100014

Zhao X, Sun Y, Zhao C, Jiang H (2020) Impact of precipitation with different intensity on $\mathrm{PM}_{2.5}$ over typical regions of China. Atmosphere 11:906. https://doi.org/10.3390/atmos11090906
Zheng C, Zhao C, Li Y, Wu X, Zhang K, Gao J, Qiao Q, Ren Y, Zhang $\mathrm{X}$, Chai $\mathrm{F}$ (2018) Spatial and temporal distribution of $\mathrm{NO}_{2}$ and $\mathrm{SO}_{2}$ in Inner Mongolia urban agglomeration obtained from satellite remote sensing and ground observations. Atmos Environ 188:50-59. https://doi.org/10.1016/j.atmosenv.2018.06.029

Publisher's Note Springer Nature remains neutral with regard to jurisdictional claims in published maps and institutional affiliations. 